\title{
Landscaping of green areas in the urban layout of midtown Lublin
}

\author{
Natalia Przesmycka \\ https://orcid.org/0000-0002-1755-2448 \\ n.przesmycka@pollub.pl \\ Katedra Architektury, Urbanistyki I Planowania Przestrzennego Wydziat \\ Budownictwa i Architektury Politechniki Lubelskiej
}

\section{Kamila Boguszewska}

https://orcid.org/0000-0002-1513-2490

k.boguszewska@pollub.pl

Samodzielna Pracowania Architektoniczna, Wydział Budownictwa i Architektury Politechniki Lubelskiej

\begin{abstract}
Today's Lublin midtown has been shaped through both spontaneous and planned change. The oldest existing form of green landscaping in midtown Lublin are its convent gardens. Most of them have not retained their former character which was influenced by both changes in ownership and functionality. Planned green area landscaping as an element of urban composition appeared in Lublin for the first time at the beginning of the $19^{\text {th }}$ century. It was then that the streamlined squares, markets and streets (Plac Musztry, Krakowskie Przedmieście, church squares) as well as the newly mapped out road and rail links gained a frame in the form of trees and shrubbery. A number of trees planted in the $19^{\text {th }}$ century are still around to this day, forming a valued element of the city's cultural and natural landscape. Soon after, the first city public parks appeared (Park na Czechówce, Ogród Miejski and Park Bronowicki). The historic cemeteries (at Lipowa St., the cemetery by the Evangelical church) are a very specific variant of urban green landscape in today's midtown. This article shows kinds of planned green area urban landscaping characteristic to midtown Lublin, based on the archival source materials, project studies, literature and iconography. The transformations of forms and functionalities of the indicated areas have been studied in the period from their foundation to date. Lublin midtown's most vital public space - Plac Litewski - was the subject of detailed analysis.
\end{abstract}

Keywords: Lublin, green areas in city center, Lublin's historic green areas, Ogród Saski, Plac Litewski

\section{Introduction}

The historic green area landscaping in midtown Lublin has been preserved mainly as form and functionality, generally losing its original structure. The individual old trees still remaining (natural monuments and the socalled veteran trees) carry exceptional natural, cultural and historical value for the city as the only living witnesses to its history. When categorising the kinds of historic greenery which plays a significant part in shaping its landscape there are the following kinds in terms of function: greenery accompanying streets and squares, public parks, cemetery greenery, convent gardens and the greenery in open riverside areas. When categorising historic greenery in terms of form, there are: preserved spatial systems, preserved trees and permanently urbanisation free areas.

The historic greenery in midtown Lublin can be understood twofold: as open green areas, urbanisation free since the initial settlement development, and as green landscaping areas, maintaining its original value in terms of form and structure. In 2018 within the city's administrative boundaries there were 63 living natural monuments, including 51 individual trees, 5 tree formations, 3 espaliers and 4 alleys which are under legal 
protection $^{1}$. In the years 2019-2020, two of living natural monuments situated in the Lublin city centre (the alder - bouckhorn flourish and chestnut) were destroyed by storms and were cut down. In the studied Lublin midtown area there are 11 natural monuments.

\section{The state of studies}

Shaping urban green areas as an urban element is the subject of research interest within many fields: urban planning, geography, history, natural sciences or economics. The park and garden complexes are a particularly interesting research subject. Professor Gerard Ciołek (1954) was the first one to address the topic of historic gardens in Lublin. The park complex by Feliks Bieczyński was the subject of research of Jan Niedźwiedź (2007). The John Paul the II Catholic University of Lublin is conducting research studies in terms of natural resources and values of Lublin's parks in reference of the ecological structure (Adamiec, Trzaskowska 2012, 2014), and research in terms of the condition and behavior of particular trees is conducted at the University of Life Sciences in Lublin (Dutkiewicz, Durlak, 2016). The state of preservation of the historic alleys in Lublin's spatial system in terms of the possibility of conservation was described by Hubert Mącik (2017).

This paper is based on the results of the existing research of the authors (Przesmycka 2005, 2012; Boguszewska 2017), literary studies, comparative analysis of the available resources of iconography, archival air photography and current satellite imagery, cartography, archival source documentation from the National Archive in Lublin, the Hieronim Łopaciński Provincial Public Library in Lublin, the Provincial Conservatory of Monuments in Lublin, the Brama Grodzka Teatr NN Center and in situ inventory.

The research subject has been the shaping of green area landscaping design in the midtown area, delimited hereafter in this article. The role of public green areas - parks, squares, markets as well as street greenery in the shaping of Lublin's midtown landscape was particularly analysed, taking into account the city's urban development and the time period when the specific green areas were established. Not analysed were the historic parks located outside of the midtown area (Park Bronowicki and post-manorial parks), nor the open green areas (understood as urbanisation free in the entirety of the shaping of today's Lublin midtown - the river valleys).

\section{Historic greenery in Lublin midtown - characteristics}

In the context of the conducted research, Lublin midtown is understood as the area developed by way of the late $18^{\text {th }}$ century urban expansion, and later supplemented by the densification of the housing complex. This system's main composition axis is Krakowskie Przedmieście street with its western extension of Aleje Racławickie as well as the development area sealed by the line of Lipowa street and the valleys of rivers Czechówka and Bystrzyca. The midtown area also includes the Stare Miasto, Podzamcze, Czwartek and Kirkut districts. The Lublin midtown area analysed here is partially overlapping with the area under preservation orders (registration number A/153, A/915) as the city of Lublin Stare Miasto and Midtown urban complex.

The natural greenery areas combined with river valleys played an important role in the formation of midtown's urban layout, by creating a barrier for urban development for centuries. Until the canalisation of river Czechówka in the 1930s, this area was a continuity of natural systems. Today, the Lublin midtown is home to recreation areas and allotments organised within the river valleys. Morphologically, two areas can be distinguished: the so-called Rusałki and Podzamcza which, since the creation of Zalew Zemborzycki (1974) and the regulation of river Bystrzyca are no longer periodically flooded.

\section{Greenery as a planned element of Lublin midtown}

Greenery as an important aesthetic and functional element of cities has been noticed only at the turn of the $18^{\text {th }}$ and $19^{\text {th }}$ century, when in larger cities, private gardens have been made available to the public and the first 
free access parks had been established ${ }^{2}$. Lublin's poor technical condition of the buildings and abysmal sanitation had been noticed in late $18^{\text {th }}$ century, mainly as a result of the activities of the Boni Ordinis Commission. In view of the scale of Lublin's then urban development, in the economically impoverished city, greenery as a functional element was not scarce, but it lacked in the aesthetic and sanitary terms. In the first city plan, made specifically for the commission, the existing green areas had been outlined with special indication of convent gardens and suburban residence gardens which had been the only forms of designed greenery in the urban area (Fig. 1). Only the redevelopment of Lublin in the 1920s became the period when green landscaping was introduced as an aesthetic element of streets and squares. Streetside greenery was accompanied by courtyard gardens and garden annexes opened into the street (such as Bernardyńska, Narutowicza, Krakowskie Przedmieście) which had been a transitional form between a free access square and a private garden. Lublin's first public park was established in the Jewish quartier area and so in an area with the worst sanitary condition. It was meant as an attempt to increase the district's health benefits ${ }^{3}$. Trees were planted and paths were made on both sides of river Czechówka. Sadly, the park was demolished just a few years later. The next park had been established in a more favourable location and this one was preserved till this day.

\section{Convent and private gardens}

Convent gardens can be viewed as the oldest form of green landscaping accompanying Lublin's urban development. The Dominican abbey, the oldest of Lublin's convents, was located in "the city within the walls". The most monastery foundations took place in the $17^{\text {th }}$ century and, as a result, there were 18 of them in late $18^{\text {th }}$ century. The new urban development located in Lublin's suburbs also contributed to their spatial expansion, but the land takeovers and the creation of "jurydyki"4 (Mazurkiewicz, 1956, p. 33-34) in time added to the city's economic decline. The historical events and processes from the late $18^{\text {th }}$ and early $19^{\text {th }}$ century have caused the decrease of Lublin's political, economical and cultural importance, its marginalisation and, as a result, the desolation of parts of the monasteries. In this process there is a visible similarity to the other former Crown Tribunal cities such as Cracow (Hodor 2012). The cessation of the monasteries from early $19^{\text {th }}$ century resulted in the introduction of new functionalities - military, and later generating - to the abandoned buildings. The convent gardens usually remained urbanisation free areas even after their function or ownership had changed.

The gardens of the Carmelites order, located along the Western side of the city's walls, have been transformed into a market square in the $19^{\text {th }}$ century. In the 1950s, a bus station was established in the southern part of the area, and the remaining space was turned into a square. Around 2000, the area was bought by a private investor with an investment purpose. A shopping mall was to have a few-storey underground parking place and an underground connection with the commercial part in the old town.

Many former convent garden areas in Lublin midtown now serve as parking facilities (Bernardines, Carmelites). The degradation of the historic tree stand in the small garden area adjacent to today's Szpitalna street in front of the Carmelites church is particularly visible. For a number of years, it has been used as a parking place and the old-growth forest is withering.

Other than the convent gardens in Lublin's suburbs, there were also gardens which accompanied the properties built from the $16^{\text {th }}$ century and owned by nobility and baronage. They did not receive a complete research approach. In a list from 1738, 47 such properties were mentioned: 11 described as palaces, 26 - courts, 10 - manors (Wójciuk 2015, 183). Some of them had small gardens, some visible as schematic representations in the cartography (Tretter 1803, Bieczyński 1829). The gardens were quartered in form, with individual parts

2 London's Hyde Park is considered the oldest city park, after it was made accessible to the public at the end of the $16^{\text {th }}$ century. L. Majdecki, Historia Ogrodów, PWN, Warszawa 1978, p. 670

3 It was established in 1827 on the initiative of the president of the Lubelskie Voivodeship Commission, Ignacy Lubowiecki, between Lubartowska Street and now non-existent Szeroka Street, in the area of the former pond on the Czechówka River. Przesmycka, N. 2005. „Przeobrażenia historycznych terenów zielonych Lublina do 1939 roku" In Teka Komisji Architektury, Urbanistyki i Studiów Krajobrazowych: Teka Commission of Architecture Urban Planning and Landscape Studies, vol. 1, 157-167. Lublin: PAN O. Lublin.This location of the garden, in the vicinity of the most neglected, overcrowded and unhealthy Jewish quarter, was an example of the urbanists' approach to social issues at that time.

4 A legal entity in the Polish legal system from bygone centuries (originating from Latin: iurisdictio, jurisdiction), denoting a privately owned tract of land within a larger municipality, often right outside the royal city, or as an autonomous enclave within it, https://en.wikipedia.org/ wiki/Jurydyka; Orders of Franciscans, Augustinians, Jesuits, Dominicans, Carmelites and Brigadines had monastic jurisdictions. 


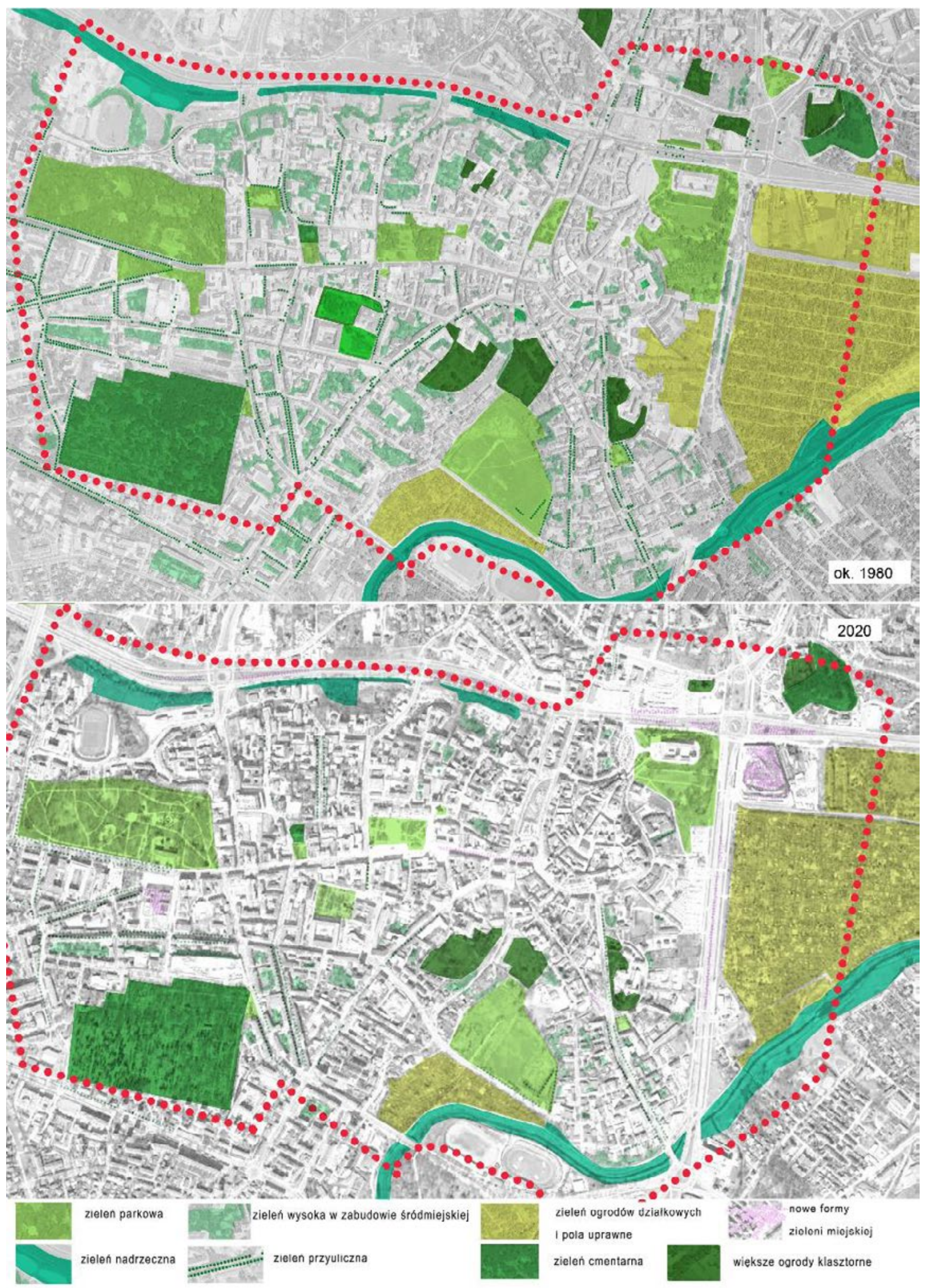

Fig. 1. A comparison of historical greenery in Lublin downtown 1980, 2020 by authors 
separated by espaliers or hedges. These gardens did not survive to this day, but the ownership boundaries marked by them have become the basis for street designation in the $19^{\text {th }}$ and $20^{\text {th }}$ century.
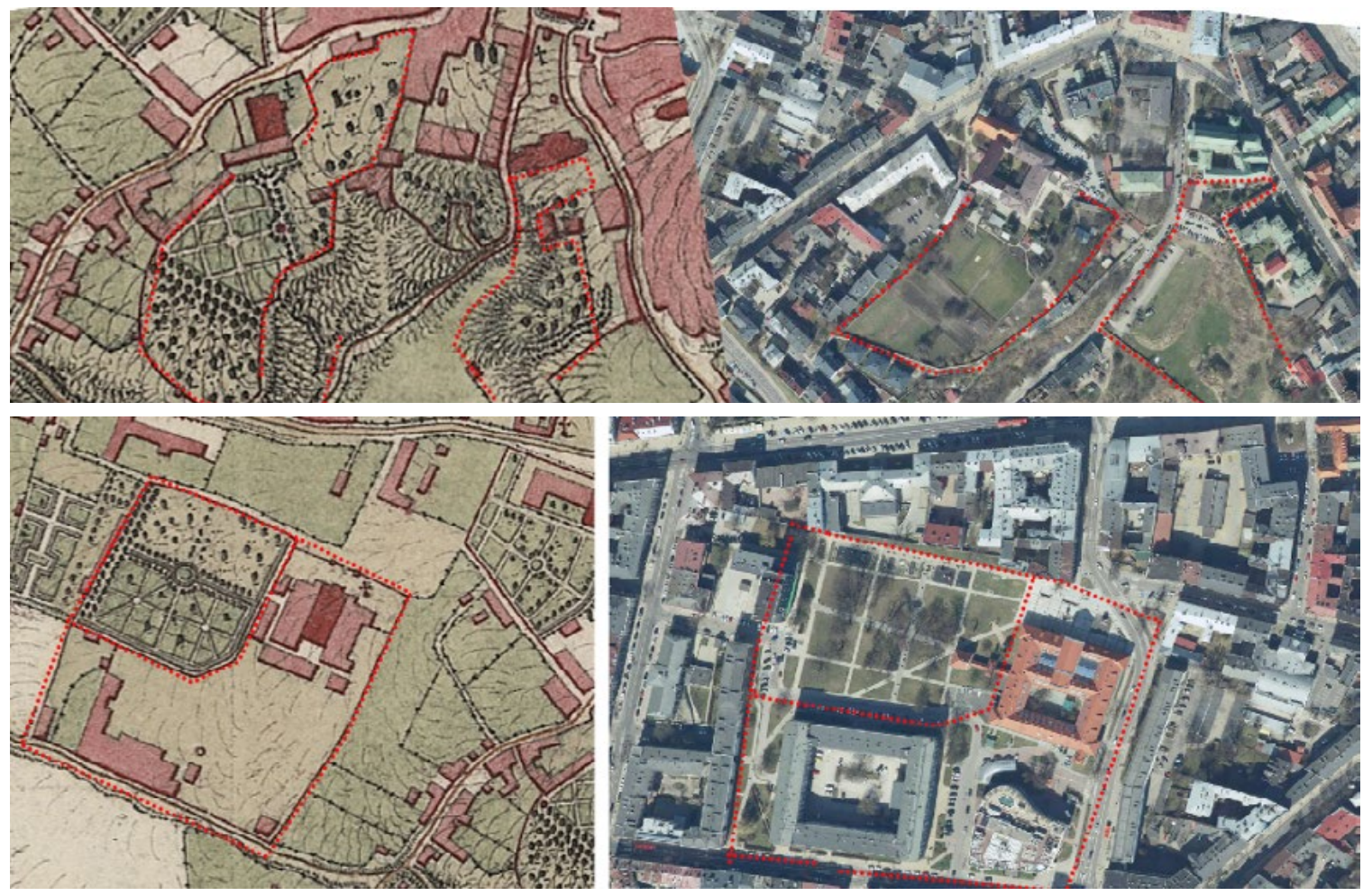

Fig. 2. A comparison of green areas of the Visitandine (post-Brigettine) and Bernardine monasteries. 1803, 2020. Source: Plan der West-Galizischen Kreis-Stadt Lublin nebst der umliegenden Gegend. Johann Tretter Hauptmann im G.u.M. Staab. Nebenkarte: Ansicht von Lublin, 1803, 2020 - Geoportal.gov. developed by authors.
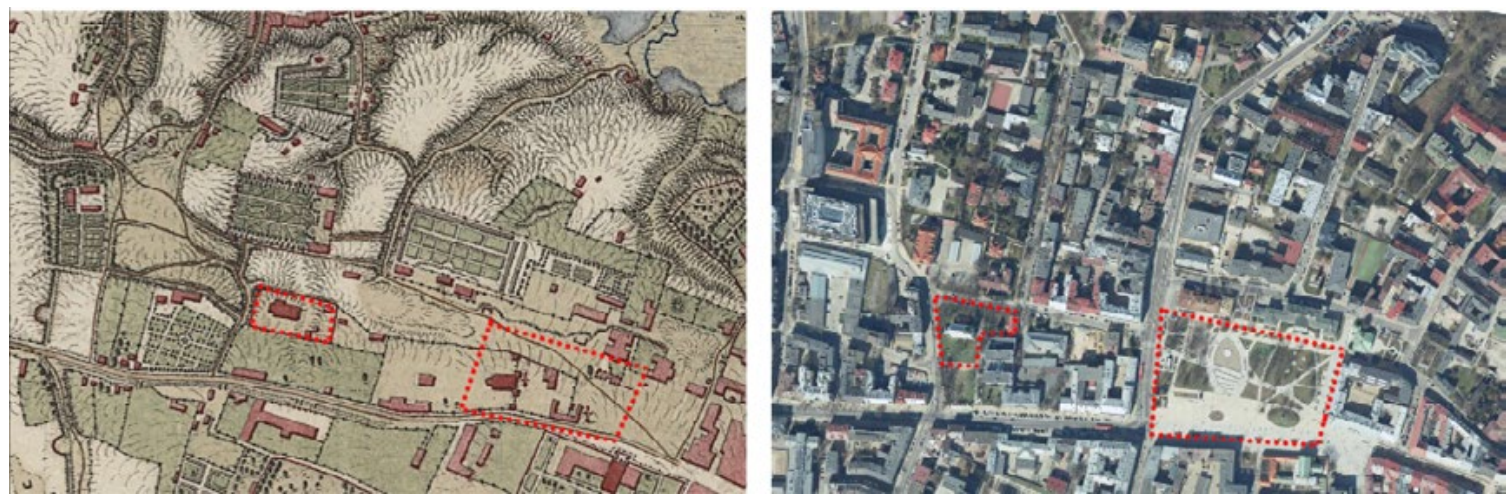

Fig. 3. Gardens accompanying palaces and manors in the northern part of Krakowskie Przedmieście. The green area by the Evangelical church of Augsburg (on the left) and Litewski Square (on the right) was marked. Source: Plan der West-Galizischen Kreis-Stadt Lublin nebst der umliegenden Gegend. Johann Tretter Hauptmann im G.u.M. Staab. Nebenkarte: Ansicht von Lublin, 1803, 2020 - Geoportal.gov., developed by authors. 


\section{Streetside greenery}

In the initial years of the Polish Kingdom's existence, Lublin - which had become the second largest city in the Kingdom after Warsaw - was abandoned and ruined. After the establishment of the Zamość Fortress it became a major hub between the Kingdom and Russia, gaining in military and political importance. The 1830s was a period of fundamental changes to the city's appearance. Lublin's redevelopment between 1815 and 1830 mainly associated with the charting of new traffic routes: warszawski, lubartowski and zamojski (with Warsaw, Lubartów and Zamość) as well as the implementation of squares: Cathedral, Łokietka (in front of the city hall), Musztry (Litewski) and Bernardyński (Wolności). All these investments were accompanied by greenery - planting of trees, lawn and greenspace arrangement. When analysing the available iconography, a tendency is noticeable to plant public spaces with Lombardy poplars. They were planted in the sorted spaces of squares: at the Brigettine cloister, in Krakowskie Przedmieście ${ }^{5}$ and even in the Old Town, at Grodzka street, in front of St Michael's church ${ }^{6}$.

The entry roads into towns and cities were often planted with linden and chestnut trees (Przesmycka 2012). Roadside trees were "public property" and destroying or cutting them down was punishable with a fine. The threat of a punishment was usually not enough of a deterrent: it was common practice to cut down roadside trees as a way to dry the road or as firewood (Boguszewska, p. 47-48, 2017). Lombardy poplars were also planted along the road to Zamość, Lubartów and new road to Warsaw as well as some streets in the more densely built-up areas and the reorganised squares. No trees from that first period of replanting of road links have survived to this day, but the "lost" specimens were replaced by different trees as time went by and so the streetside greenery in the streets and former roads can be considered historic.

The establishment of the trench foot on the western side was of great importance to the city's urban development. They were both a symbolic and real city boundary on the axis of the natural direction of its expan$\operatorname{sion}^{7}$. Located outside of the trench foot, the late $18^{\text {th }}$ century cemetery is not in midtown Lublin. Serving as a cemetery border, the street running along the trench line was planted with linden, hence its name - Lipowa. Few of the $19^{\text {th }}$ century linden trees have survived until the 1980 s. The city cemetery at Lipowa is not only a valuable architectural complex but is also the second largest (after Ogród Saski) high greenery areas in midtown Lublin, with many species and historic tree specimens (Dąbski, Oleś 2006).

The historic greenery in midtown Lublin described above, with the exception of the Lipowa Street cemetery, is no longer there. The trees along the streets in Lublin's strict center (Krakowskie Przedmieście, Królewska, Narutowicza) were planted from mid-19 th $^{\text {ch }}$ century. When analysing the available iconography, it can be stated that among the used species there had been Lombardy poplars, linden, maple, acacia and chestnut trees (Królewska street). The trees were secured by picketing, but unfavourable development conditions caused repeated replacement of the picketing to be necessary. The tree stands suffered major damage after World War I (APLA, 2011, p. 10). In the mid-war period, trees were re-planted within the existing midtown streets, and all newly designed streets also were planted with trees, keeping in mind the scale of the tree, its placement with reference to the road, the urbanisation and underground infrastructure and proper securement ${ }^{8}$. The trees planted in the $19^{\text {th }}$ century have been preserved as relic specimens until the 1980s in the area of Lipowa, Narutowicza, Karmelicka, Krakowskie Przedmieście (at Litewski Square). The mid-war plantings were still present in the area of Szopena, Skłodowskiej, Okopowa, Radziszewskiego and Aleje Racławickie until the 1990s. In the early noughties, still in good condition, the trees from the PRL period (such as the Lombardy poplars in Hempla, the ash trees in Kołłątaja) had been cut down, and the red ash trees (Narutowicza, Peowiaków) had suffered the most due to the renovation of the sidewalk (2016-2017).

5 Lombardy poplars were planted between the buildings of Św. Ducha hospital and the town hall, and in front of the town hall, a row of deciduous trees was planted, with a spherical shape, separated from the pavement by a wooden fence. Cegliński J. according to A. Lerue, 1857, Muzeum Lubelskie Kat. 94,

6 Iconography analysis: J. Cegliński, collegiate of St Michael before its demolition in 1846-1852

7 The terrestrial city trenches in the line of the present Lipowa St. date back to the $18^{\text {th }}$ century. In the nineteenth century these were so-called consumption trenches, making it impossible to enter the city without collecting the postage fee, which was paid at the collection points in the tollbooths.

8 General and detailed plan for the construction of an area bounded by the streets of Lipowa-Rury Jezuickie-Gtęboka and the cemetery in the city of Lublin LPU WP UM Archive 
In the 1990s, new plantings in the Krakowskie Przedmieście area had been introduced, during the creation of traffic-free areas between Litewski Square and Brama Krakowska. The rounded varieties of false acacias and maple trees were planted, and they had survives several years. Nowadays (2018) a new planting was introduced in the Krakowskie Przedmieście area, with a species heretofore unknown in Lublin - sycamores. Over the last few years the withering streetside trees in the midtown have been successfully replaced by trees in concrete pots - linden, combined with low bushes and perennials. The lifespan of these trees is very short and heavily dependent on their intensive care.

Nowadays, street greenery decorations on various scale have become a popular occurrence: from pots hanging off street lamps, to pots with grass, to flat-formed trees, put outside in the summer. Such temporary green landscaping still does not solve the problem of its lack in the urban landscape, and the utilised forms and species are a result of current trends, and not a well thought out street image composition.

In terms of the need for shaping the streetside greenery in midtown Lublin, a positive phenomenon is the perception and recognition of the need to implement such greenery into the street landscape by the residents themselves. The citizen's budget, increasingly popular in recent years and since 2016 known as the Green Citizen's Budget, is a platform which best showcases the needs of the residents. From its very first day, the need of replanting streetside trees in midtown Lublin had been raised.

\section{Ogród Saski (Miejski) [Saski Garden]}

In 1837 the public garden was established in the area formerly owned by the Dominican Friars Minor monastery, extending between the new road towards Warsaw, Wieniawa town development and the western border of Lublin, marked out by the previously mentioned trench foot line and the adjacent cemetery. The park was designed by the engineer Feliks Bieczyński in the landscape style on an acreage of around 13 hectares ( 32 acres). The area's natural hilly landform was used in the design of the park by incorporating the landscape interiors into it. Euzebiusz Maj (2007) points out the strong influence of the idea of Duchess Izabela Czartoryska from Puławy on the shaping of the landscape public park in the style of the "arboretum".

In the first phase of setting up the garden trees and bushes from the nearby Czechowski forest were planted. The Lublin residents were encouraged to "supply various bushes from their own gardens", and the more valuable plants were shipped over from other European gardens, such as Hamburg (Łodzia-Bieczyński 1854). Meadowgrass was used for sodding the lawns, and the hay was held for sale 9 . Other profitable plantations included nurseries of poplars and white mulberries for raising the silkworm. In time, the park also included elements of urban design, buildings and pavilions: a gazebo - confectionery, a gazebo rotunda, a cross-plan gazebo, two garden fountains (a 19 ${ }^{\text {th }}$ century one and another, octagonal, from the mid-war period), and a sundial. A barometer with a thermometer was located at the entrance ${ }^{10}$. During World War II the park maintained its functionality. The Germans took good care of the garden and even built a new facility - a Tirol style, wooden, thatched roofed tavern. After the end of the occupation the German tavern was disassembled and after 1945, the garden fence and gate had been destroyed. Although the fence was reinstated, but it was low which was a factor in its increasing devastation.

Between 1945 and 1947, the Urban Greenery Management performed a refurbishment of the park (new plantings and a correction of the alleys). In 1953, in the place of the former salt depository on the southern border of the park the Dom Partii (House of the Party) building was raised, and subsequently in 1960 the "Pod Jesionem" cafe and the band shell in the north-western park of the park were built. In the 1970s and 80s the condition of the preserved greenery continuously worsened. In this period, the works were done in a sampling manner and consisted of ad hoc logging of withered trees, and the deadwood was only removed when the hanging branches constituted a direct threat to the people walking the alleys. The increasing air pollution is also a negative influence on the condition of the high greenery, especially conifers ${ }^{11}$. It was only in the mid-1990s, at

9 APL, 22, AmL 1809-1874, sygn. 570.

10 The design of the park takes into account the preservation of the baroque figure erected on the mound, marking the place of former burials.

11 https://lublin.eu/mieszkancy/srodowisko/zielony-lublin/parki-w-lublinie/ogrod-saski. 
the commission of the Municipal Office of the Department of Public Utilities, a project of managing the existing stands was developed.

a)

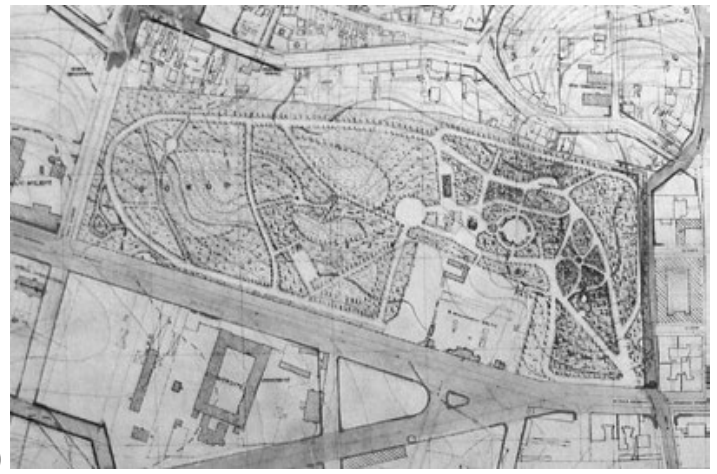

b)

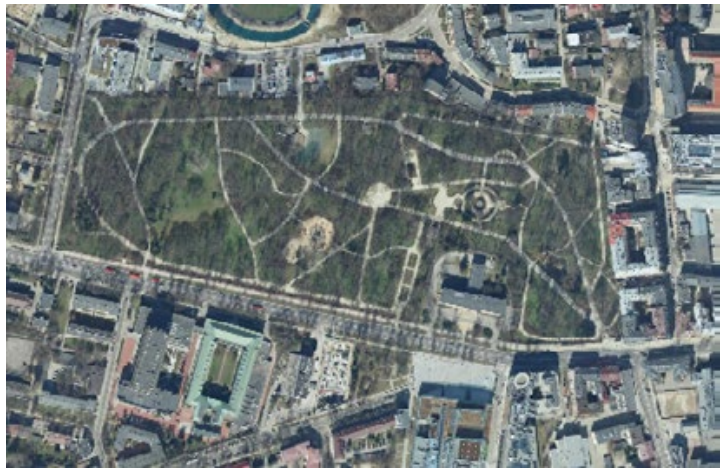

Fig. 4. Ogród Saski on perimetral plans from 1928 and on satellite imagery from 2018. Source: LPU Archives, UM Lublin Planning Department, geoportal

a)

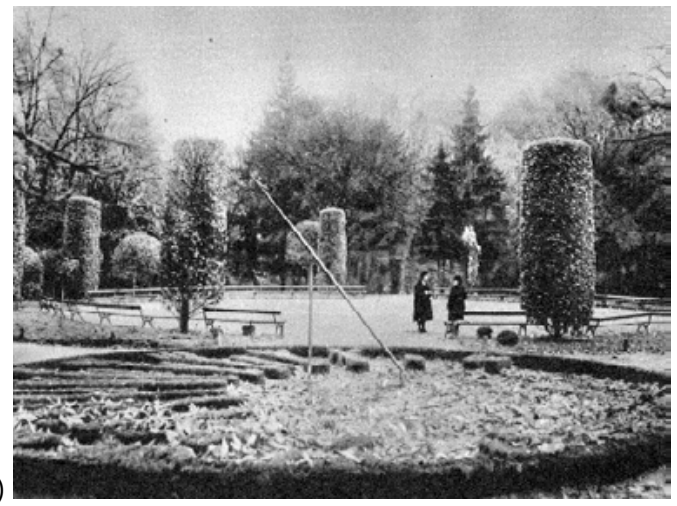

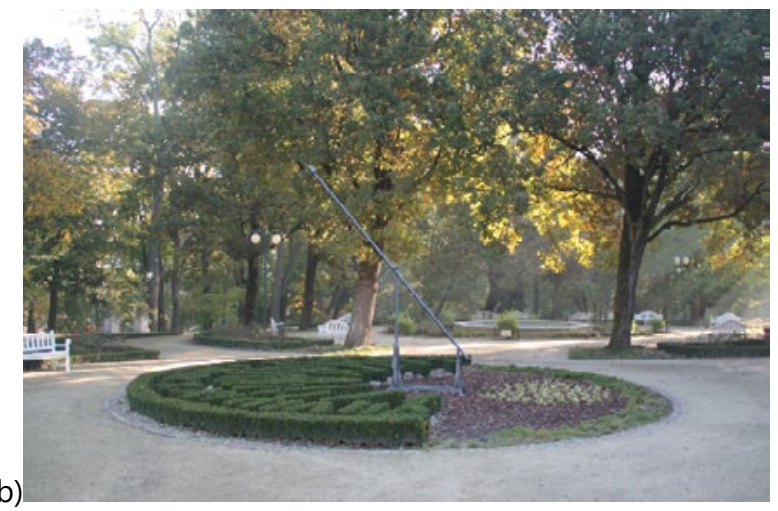

Fig. 5. Leisure zone with a sundial. Photography from the 1930s, source: The Poland Reborn Decennary commemorative book 1918-1928 published by llustrowany Kuryer Codzienny, Światowida na Szerokim Świecie Kraków-Warszawa 1928, status 09.2018, photo by W. Pawlak

Between 2009 and 2013 a $12.7 \mathrm{mln}$ PLN refurbishment of the garden took place ${ }^{12}$. The works included land leveling, removing of the erosion caused by rainwater and correcting the landform at the banks of the lower pond, as well as increasing the number of park benches to reach a total number of 150 seats. New paving was implemented - instead of asphalt alleys loam-shingle paving in paths with smaller tilt and asphalt with granite framing in those with bigger tilt. The pond basin and the water course bed were rebuilt. The playground was expanded and refurbished with the application of typical catalogue amusement apparatus. It was planted with a circle of the rounded variety of false acacias - a decision based on the iconography by Gerard Ciołek ${ }^{13}$. During the refurbishment, 385 trees were cut down (among 2.5 thousand) with the aim of making the original park composition clearer - which in turn was met with public uproar ${ }^{14}$. New historicizing elements of urban gardening design were introduced in the park, as well as an aviary for ornamental birds.

Nowadays the role of Ogród Saski is mainly its recreational function (walks, picnicking, concerts). After the refurbishment of the garden, dogs and cycling are no longer allowed in its grounds. The vicinity of this historic greenery also has a large influence on the property market. In 2012, the adjacent Kosmos cinema was

12 Restoration of Ogród Saski in Lublin - scope of the project and historical outline, information brochure, published by Gmina Lublin, 2013.

13 When analyzing the list of plant species, however, it should be stated that the acacia did not exist the garden at that time. List of detailed decorative trees - shrubs..., the Hieronim Łopaciński Provincial Public Library in Lublin.

1419 new trees were planted and approx. 38 thousand coniferous and deciduous shrubs, as well as numerous winding crops. 
demolished and in its place, the residential building "Centrum Park" appeared. Currently, works are underway in multiple other residential buildings located in close vicinity of the park, offering high-standard apartments.

\section{Plac Litewski (Litewski Square)}

As opposed to Ogród Saski described above, Plac Litewski is a public space whose composition, development and functionality have changed multiple times over the last 200 years. The current Plac Litewski ${ }^{15}$ was created as a result of being moved to the area of the so-called Plac Na Rozdrożu - a drill square (Fig. 3). Military parades and parade drills took place there as a form of both mass entertainment and a political element. Between 1818 and 1821, the area intended for the so-called Pole Marsowe (Campus Martius) was cleared of the remains of the demolished Order of St John monastery, hardened, planted with Lombardy poplars and surrounded by barriers ${ }^{16}$. The square was around 2 hectares ( $\sim 5$ acres) in acreage, and it was divided into two functional parts: on the western side there was an open space for parades and assembly, and on the eastern side there was a wooded square with a monument of the Union of Lublin. It was to "not only serve military purposes but also at the same time decorate this part of the suburb"17.

The square was created in front of the seat of the Lubelskie Voivodeship Commission (KWL), located in the former Szeptycki palace. It was Lublin's first public green area with lawns, flowerbeds and alleys leading in the direction of Krakowskie Przedmieście. In 1826 an obelisk commemorating the Union of Lublin was placed in the axis of the building (Kurzątkowski 1985, 60) ${ }^{18}$. At the turn of 1823/24 on the western side of the drill square Czechowska street was delineated (now 3 Maja), which shaped the current Plac Litewski ${ }^{19}$. The western frontage of the square was demarcated by the neo-Gothic buildings of the Customs Office and the Regional Commission, or district, from the 1830s. (Przesmycka 2012, 80). It is assumed that the first author of the development project of the Plac Litewski greenery was Feliks Bieczyński (1852) - however, the plan project was not preserved and the degree to which the plan of greening of the whole square was executed is difficult to assess ${ }^{20}$. After the Orthodox church was built in 1876, the former drill area was developed into green spaces. The square became a sequence of piazzas. From the western side, the alleys were directing into the axis of the gateway to the church, whose immediate surroundings were gates and surrounded with bushes. On the axis of the KWL building, a wooded square was developed, directed at the mound with the Union of Lublin monument. From the Krakowskie Przedmieście side, a triple row of trees was planted. In the part near the Orthodox church the row was quaternary - including the existing trees. One of those trees was a black poplar, preserved till 2017, locally known as the Baobab. The rows of trees were also present at the western side of the square and along the transport routes by the front of the church through the entire width of the square ${ }^{21}$. In the $1890 \mathrm{~s}$, two proposals of a new development of the square were designed by the Warsaw mapper, Z. Kisielewski. Its tripartite was maintained, each with the form of a green area planned in an informal, calligraphic style (Ciołek, 1954 , p. 270). The flowerbeds in the areas of the KWL and the Union of Lublin monument were particularly decoratively designed. However, the project was never implemented - the division of the interior and the idea of the green areas was preserved. The governor's garden, together with the Union of Lublin monument, were demarcated from the space of the square with a wooden fence, the green spaces were surrounded by barriers so that the public had no access to any of them (Gawarecki, 1958, 246). The wooden fences of the squares

15 The name has been in use since about 1839. Architectural and Landscape Study of Plac Litewski, Lublin 2000.

16 We see him in this way in the painting of Filip Dąbek, "The Arrival of General Zajączek to Lublin in 1826".

17 KRSW 3659, k. 22-40, KWL do KRSW from 30.III.1820.

18 Probably on the initiative of S. Staszic, a cast-iron monument - an obelisk - was placed on the site of the former chapel. According to L. Gawroński (1985, p. 68), a monument in the form of a four-sided stone column covered with tiles, with a niche in which there were stone figures depicting Poles and Lithuanians, or according to other versions - Władysław Jagiełło and Jadwiga, was most probably funded by Zygmunt August. The monument was originally located opposite the church of the Order of St John. In 1819, during the demolition of the ruined post-monastery buildings, it was destroyed, which Staszic deplored.

19 The name of the square refers to the events of 1569 . Here, according to the tradition conveyed by the nineteenth-century monographs of Lublin during the signing of the Union of Lublin, the nobles from Lithuania who had come to the assembly in Lublin, pitched their tents. (Sierpiński 1839, 26, Zieliński 1878, 55).

20 Architectural and Landscape Study of Plac Litewski, Lublin 2000, p.16.

21 APL, AmL, sygn. 6252, s. 32-34. 
were dismantled in 1912 and replaced by low iron people stoppers, but the green spaces remained closed to the public (Dybała, 1972, 93).

The Plac Litewski redevelopment project by Henryk Paprocki stems from $1908^{22}$. As a graduate from the Petersburg Tzar Academy of Arts, Paprocki gained him architect title in 1901, and from 1902 he was Lublin's city architect (Żywicki 2010, 488). His project maintained the division of the square into three parts: the central part around the 1875 Orthodox church, the eastern part between the governor's palace and the Union of Lublin monument, and the western part, restricted by Czechowska street (today 3 Maja) and the Europejski Hotel building. Between those parts, the traffic routes were designed, linking the government buildings with Krakowskie Przedmieście. The green spaces with parterre forms, surrounding the Orthodox church and in the western part of the square were rectangular and triangular in form, and in the church-adjacent part, encircle it, creating an oval square. The lawns inside surround the hedges with rows of trees. It is most probable that the architect had skillfully incorporated with existing older trees - the oaks in the north-western corner of the square and the black poplar - into the geometric system, situating them in the corners of his designed system ${ }^{23}$.

The remaining trees are ornamental species, placed in equal distances. The green space on the axis of the Union of Lublin monument and the governor's palace has a geometric but slightly differing character. The designer customised its layout to the oblique axis which links the monument and the palace. The obelisk, placed on a mound, was accompanied by plantings of ornamental bushes placed centrally, and most of the space was covered by a vast lawn with a circular path course. In the eastern part of the square, Paprocki had designed a green space in the form of a wedge, planted with not too tall ornamental trees, which defined the garden interior of the governor's palace planting. This project was also not fully implemented, but between 1910 and 1928, Plac Litewski was rebuilt, maintaining the elements mentioned in the plan, which is visible in the preserved cartography ${ }^{24}$.

The buildings appearing at the turn of the centuries completed the Plac Litewski urbanist interiors (Victoria hotel, tenement houses with shops on the ground floors nearby the post office building, the Lublin Entrepreneur Fund building designed by Gustaw Landau (Gawarecki 1959, 104). Opposite the square, between 1912 and 1914 the new National Bank building was erected, in the place of the former customs office which was demolished in 1911, designed by W. Sołowiew, in the "Petersburg Empire" style (Gawarecki 1959, p. 99). The placement of nearly exclusively public facilities around Plac Litewski reaffirmed its existing importance. It became a representative space, a place of historical and political events (Przesmycka, 2012, 99). After Poland's regaining of independence, the Orthodox church was demolished (1923-24). In 1928 an architectural contest call was launched for the development of Plac Litewski and it was won by the architect Aleksander Gruchalski. In the mid-war period, Plac Litewski was a popular leisure spot. In the World War II period, the cast iron fences in the eastern and northern parts of the square had been removed. In the northern part of the square's center a rectangular firefighting water tank was located which, surrounded by flowerbeds, also served an ornamental purpose. It was preserved in this form till 1957 (Studium..., 2000).

In 1945, a monument of Gratitude to the Soviet Army was erected in Plac Litewski, and it dominated the central part of the square as well as the previously existing monuments ${ }^{25}$.

In 1962 the square was yet again refurbished, this time with the design of mgr inż T. Bobek and inż. arch. T. Augustynek (Miastoprojekt Lublin). Consulting on the project were prof. fine artist J. Jarnuszkiewicz and prof. G. Ciołek (in terms of green landscaping). The project adapted existing natural and spatial elements of the square, while at the same time incorporating the current aesthetic styles of the 1960s. Its spatial tripartite was maintained. The fountain was given a hexagonal form which was popular at the time, the existing trees were preserved and highlighted, especially the black poplars. New paving with geometric divisions was implemented. The square became an exposition space for three monuments: the $3^{\text {rd }}$ May Constitution, the Union of Lublin and the dominating Gratitude monument. After the change of political system, the latter was disassembled (1990). Ten years later, with the initiative of the Lublin branch of the Piłsudczyk Association, attempts

22 Site plan of reconstruction of city squares. Paprocki H., Muzeum Lubelskie, nr inw. ML/RR/338.

23 The design of the project does not clearly show which trees were existing, but their age allows to recognize that in 1908 , they were already adult specimens.

24 Lublin city plan from 1912, Stelmasiewicz M., APL, sygn. 8623, Lublin city plan from 1919, APL, PmL, sygn. 13.

25 The monument of the Konstytucja 3 Maja had been moved to the side, Unii Lubelskiej and the Tomb of the Unknown Soldier. 
were made to erect an equestrian statue of Marshal Piłsudski in Plac Litewski. The proposed location was met with resistance from the conservation bodies, due to the lack of inclusion of the qualities of the square's urban composition. Despite the disagreement, the statue was erected on the basis of roadworks investment application of a "temporary object in the form of the equestrian statue of Marshal Piłsudski" (Landecka, 2008, 77). The statue in its unchanged form and location still exists to this day.

The analysis of available iconography shows that since the 1940s, the composition of Plac Litewski was dominated by the solitary tree - the black poplar (known as the Baobab from the mid -1900s). In time, the tree become not only a dominant of the system but also the symbol of Plac Litewski and one of Lublin residents most beloved meeting spots.

In 2000, an Architectural and Landscape Study of Plac Litewski in Lublin was drafted, including detailed design outlines. The inventory created for the purpose of the study showed 241 trees, including five natural monuments: two common oaks ( 317 and $296 \mathrm{~cm}$ in circumference with a height of 1.3 meters), two Norway maples (267 and $245 \mathrm{~cm}$ ) and a black poplar (484 cm in circumference) (Studium..., 2000, 29). The trees' age analysis, prepared for the purpose of the study, indicated the existence in Plac Litewski of 19 trees estimated to be around 100 years old (including 5 natural monuments) and 8 trees up to 100 years old, and their health and vitality were estimated for around $70-90 \%$. The Baobab's vitality was estimated for $70 \%$.

Before the Plac Litewski redevelopment project was implemented, a number of architectural calls of various ranks was organised $(1995,2007,2008,2010)^{26}$.
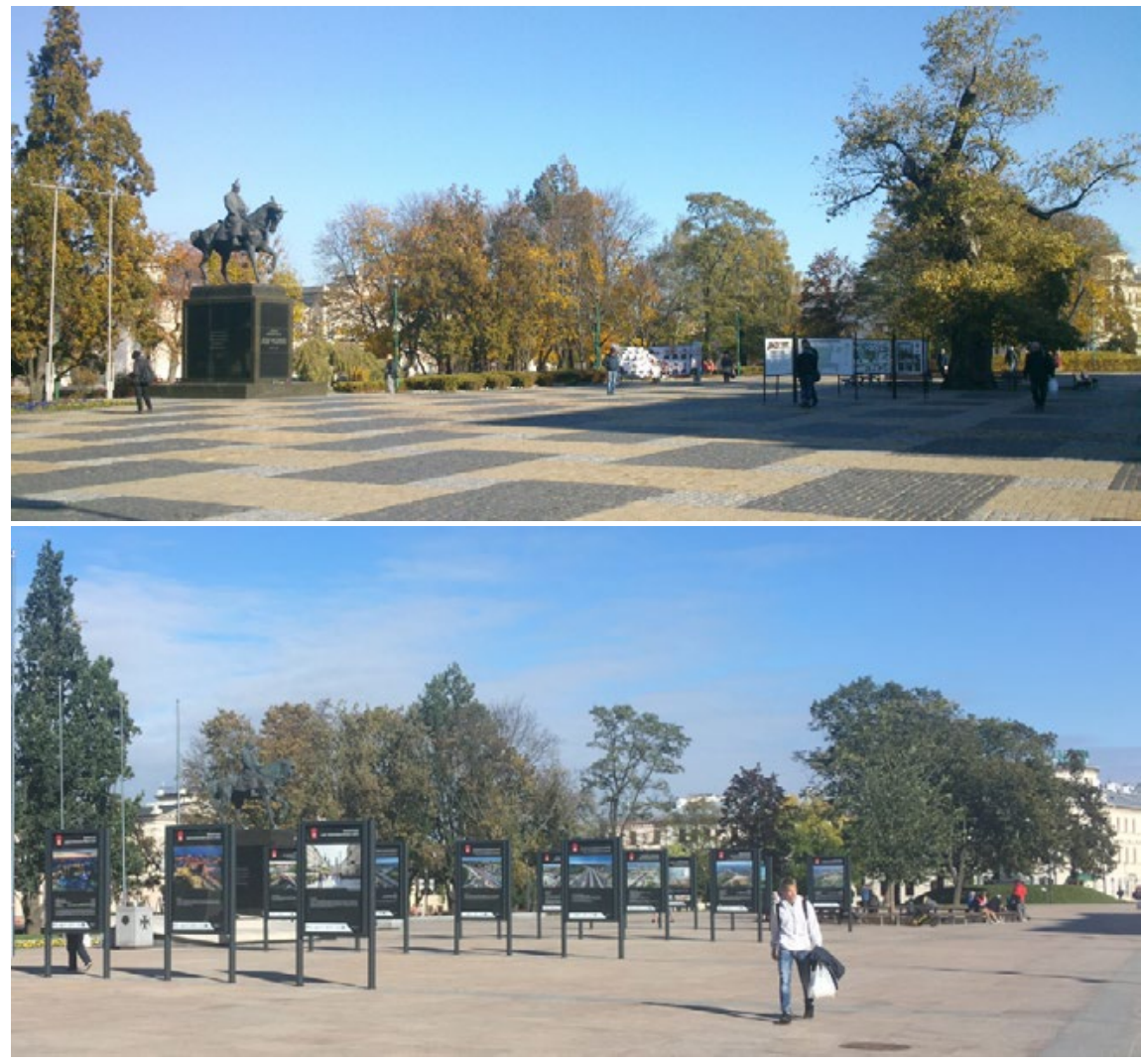

Fig. 6. Plac Litewski, view to the north-east. Condition pre-modernisation (10. 2015) and post-modernisation (09. 2018) - after the removal of the black poplar known as the Baobab. Photo by N. Przesmycka

26 In 1995, the competition for the concept of square development, in 2007 the Gazeta Wyborcza competition, gave a pretext to discuss the need to change the development of the square. In 2008, international workshops took place - a competition, evaluated among others by prof. Jan Gehl. On June 28, 2010, a town-planning and architectural one-stage urban competition was opened to develop a conceptual design entitled "Revitalization project of the Plac Litewski in Lublin" organized by the City of Lublin in cooperation with SARP, after: http:// www.sarp.krakow.pl/konkursy, 149,Konkurs_na_Plac_Litewski_w_Lublinie.html. 
The architectural project was delivered by the Lublin-based Architectural Office of Urszula and Jacek Ciepliński, IDEA s.c. The office was awarded third prize in an international architectural-urbanist contest organised by Lublin Municipality with the participation of SARP in 2010. The project also constitutes the continuation of the composition ideas of the B.A. IDEA project team in the 1995 concept project, awarded with second place in the architectural-urbanist contest for the development of Plac Litewski with the transformation of a part of Krakowskie Przedmieście and Plac Łokietka into the so-called Deptak (=boardwalk), (the first prize was not awarded) ${ }^{27}$.
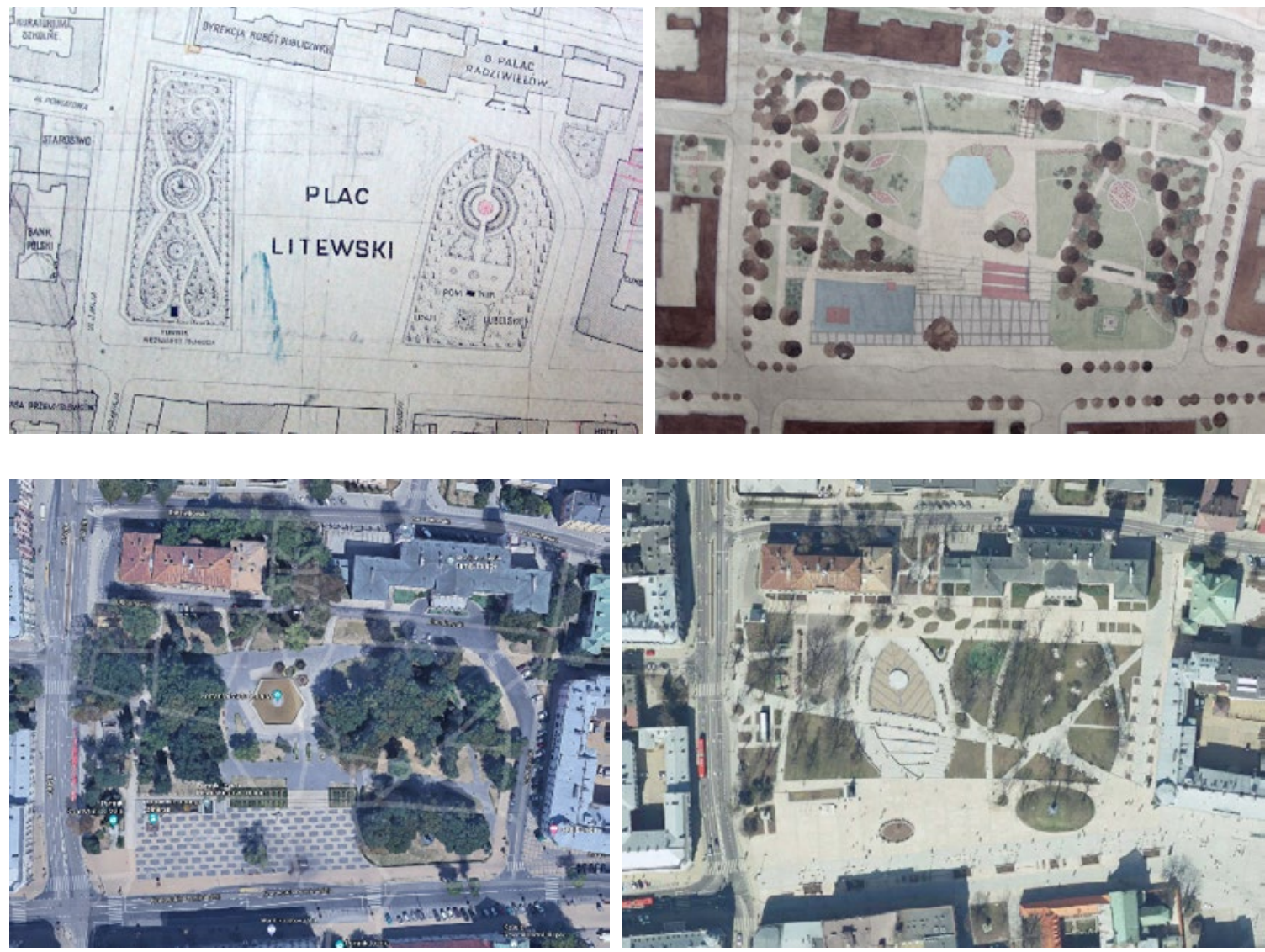

Fig. 7. A comparison of the development of Plac Litewski at various times: 1928, 1962 (project), 2017, 2018, source: Archives of the Lublin Town Hall, googlemaps, geoportal.gov

After the redevelopment, Plac Litewski has become an attractive space for many groups of users. The implementation of modern architectural and composition elements highlights the preserved elements of the historic green landscaping and the old trees. The designers planned for the exposition of the black poplar, but during the construction works the decision was made to cut it down. It was a very controversial matter and the subject of widespread debate in Lublin media. The tree was removed from the natural monument list based on a dendrological evaluation (Durlak, Dudkiewicz, Dąbski, 2016). The analysis of the condition of the tree showed the circumference of $506 \mathrm{~cm}$ at 1.3 meters, the height of 16 meters and the tree top range of 7 meters. It must be pointed out that the tree top at the time was very much reduced, asymmetrical and largely lowered due to the many years of maintenance. The tree trunk from the southern side all the way to the top was devoid of

27 THE CONCEPT FOR CHANGING THE PLAC LITEWSKI IN LUBLINPURCHASER: Municipality of Lublin pl. Króla Władysława Łokietka Lublin CONTRACTOR: Konsorcjum - Lider - BIURO ARCHITEKTONICZNE IDEA s.c. Jacek Ciepliński, Urszula Cieplińska ul. Reymonta 12, Lublin, after: https://docplayer.pl/43137719-Koncepcja-zmiany-zagospodarowania-placu-litewskiego-w-lublinie.html. It must be also mentioned that the Architectural Office IDEA s.c. were the authors of the redevelopment projects of Krakowskie Przedmieście in 1995-96 and 2003-2005. The redevelopment of Plac Litewski was consistently continued in the modernisation of Krakowskie Przedmieście, concluded in October of 2018. 
outer bark, with the occurrence of oyster mushroom sporocarps. The tomography showed that the damaged timber at the height of 1.3 meters constitutes $71 \%$ of the cross section, the "technically fit" timber was $15 \%$ and the remaining $14 \%$ is in a transitional phase (Durlak, Dudkiewicz, Dąbski 2016. 8-9). The bad condition of the tree and the risk of the possible treefall or breakage were the basis of formulation in the expertise of the request to remove the tree from the natural monument list and to remove it from the square area for safety reasons. (Durlak, Dudkiewicz, Dąbski, 2016, 10).

The removal of the Baobab coincided with the celebrations of 700 years of Lublin's location. The tree, going back to the times of Feliks Bieczyński, still had living green leaves at the time of its chopping which added a particularly dramatic aspect to its "execution". Euzebiusz Maj, art historian, and above all gardening specialist and author of many green landscaping projects in Lublin, in his open letter to the Lublin authorities indicated the tree's cultural importance. After the fall of the January Uprising in 1863, in a period of yet another national mourning, Plac Litewski in Lublin, arranged by Feliks Bieczyński was a place which in a way expected the introduction of a symbolic object with a meaning and importance hidden from the occupant. The black poplar became that symbol - as a tree of great vitality and mammoth dimensions - was soon to weaken the spatial exposition of the Orthodox church, built by the Russians in $1874^{28}$.

The city center of Lublin, apart from the obvious service and cultural functions, is also a residence zone. The historical green in Lublin midtown, apart from natural, composite and aesthetic functions, is an element of the life quality for the inhabitants.

The quality of life is not only linked to the very presence of urban greenery, but also to the type of environment in which they live. Except for parks, Lublin city center is practically free of high green, which is most beneficial for the feeling of quality of life. This relationship also shows research based on cartographic modeling (Krukowski, 2018, p. 20-21).

In 2019 under the Civil Budget, a study on the quality of life assessment was carried out in the various districts of Lublin. The Lublin midtown and the Lublin Old Town, against the background of other districts, were located in a group of typical living quarters. As investment priorities in the second place (after new parking places), the residents indicated the need to develop and care for green areas. In the case of Lublin midtown and the Lublin Old Town, this need is at the top of the list, which is different from those declared by the general population of Lublin and clearly demonstrates the needs.

\section{Summary}

There are currently 61 greenery areas under conservation protection in Lublin's administrative boundaries. 34 among them are registered as historical monuments by administrative decision where it is stated explicitly that the greenery is under protection (Mącik, 2017). ${ }^{29}$ When considering the Lublin Old Town and midtown urbanist complex area, one needs to note the role of historic greenery in the shaping of the urban landscape and structure. The convent gardens and palace-manor plantings largely influenced the ownership division. The street layout in Lublin midtown was to a large extent conditioned by the placement of the boundaries of convent estates and gardens. To this day 14 convent estates remain, of which only six maintained the continuity of their functionality (Pudelska, Mirosław, 2011, 81-91). An important group are the gardens which are not listed, but accompanying the historic buildings. Lublin midtown urbanist layout was largely influenced by the now-defunct garden of the Discalced Carmelites monastery. It covered the area of a prolonged, triangular shape, expanding along the former city walls. From the $19^{\text {th }}$ century a market square appeared in its place, then transformed into a plaza after World War II, and currently into a construction site of a multilevel underground parking facility. Another garden in the very midtown is the largest preserved and still functioning convent garden - the (formerly Bridgettine) garden at Dolnej Panny Marii street. It is a community garden with cultivation of fruit and vegetables and an orchard. These urbanisation free areas are now of exceptional natural, landscape and aesthetic value.

28 The statement of Euzebiusz Maj, source|: http://teatrnn.pl/historiamowiona/swiadek/Maj\%2C_Euzebiusz_\%281940-_\%29?tar=44502

29 The urban complex of the Old Town and midtown of the city of Lublin, registry no. A/153, entry date: 27.01.1967, Trees in the midtown in road lanes registry no $\mathrm{A} / 153$. 
The biggest threat to the Lublin midtown greenery is, among others, the lack of spatial development planning in this part of the city, which can result in the desire to introduce investment plans in this location, interfering with the urbanisation free areas. What is also problematic is the new design approach to the public green areas which focuses on following current trends and fashions and often results in the introduction of alien species, not corresponding with the historic landscape of Lublin.

\section{Literature}

[1] Adamiec P., Trzaskowska E., Diagnoza stanu i walorów parków miejskich Lublina oraz wytyczne do ich ksztattowania, "Teka Komisji Architektury, Urbanistyki i Studiów Krajobrazowych", OL PAN, 2012, 8/1: 7-18.

[2] Adamiec P., Trzaskowska E., Wartości przyrodnicze parków historycznych Lublina na tle struktury ekologicznej miasta, "Prace Komisji Krajobrazu Kulturowego", nr 25/2014: 57-59.

[3] APLA, Pamiętajcie o ogrodach, Biuletyn informacyjny, APL Lublin, nr 5, wrzesień 2011.

[4] Boguszewska K., Zieleń pasów przydrożnych w historycznej ikonografii Lublina, W: Roślinność pasów przydrożnych Lublina: potencjał i zagrożenia; [Red:] Trzaskowska Ewa - Lublin: Urząd Miasta Lublin, 2017, s. 47-58.

[5] Ciołek G., Ogrody Lublina w XIX wieku, „Ochrona zabytków”, r. 7, nr 4 (27), Warszawa 1954.

[6] Dąbski M., Oleś A., Analiza dendrologiczna zabytkowego cmentarza przy ulicy Lipowej w Lublinie. / The dendrology analysis of the historic cemetery on Lipowa street in Lublin. Przyroda i miasto, 8: 434-440 (in Polish), 2006.

[7] Durlak W., Dudkiewicz M., Dąbski M., Ekspertyza dendrologiczna dotycząca określenia stanu zdrowotnego topoli czarnej (Populus nigra L.) - pomnika przyrody na Placu Litewskim w Lublinie. Lublin Grudzień 2016.

[8] Dybała J., Plac Litewski w Lublinie. Dzieje zabudowy i założenia urbanistycznego, "Roczniki Humanistyczne”, 1972, T. XX, z. 5, s. 71-101.

[9] Dziesięciolecie Polski Odrodzonej - księga pamiątkowa 1918-1928, wydawnictwo i nakład Ilustrowanego Kuryera Codziennego, Światowida Na Szerokim Świecie, Kraków-Warszawa 1928.

[10] Gawarecki H., Zabytki miasta, Lublin - przewodnik, 1959.

[11] Gawarecki H., Stanisław Krzesiński: Dwa wrażenia...czyli Lublin jakim był w roku 1827 i jaki jest w roku 1877, [w:] „Rocznik Lubelski", R. I, Lublin 1958, p. 246.

[12] Gwaroński I., Historia w pomniku zamknięta, [w:] „Kalendarz Lubelski”, Lublin 1985.

[13] Hodor K., Ogrody klasztorne i ich rola w kształtowaniu tkanki urbanistycznej miasta Krakowa. „Czasopismo Techniczne”, 6A-2012, z. 19, R. 109.

[14] Krukowski M., Cartographic modelling of the urban quality of life - aspect of green areas in the City of Lublin (Poland), Annales Universitatis Mariae Curie-Skłodowska, Lublin - Polonia, Vol. LXXIII Sectio B 2018, 7-27.

[15] Kurzątkowski M., Najpiękniejszy w Polsce? Rzecz o placu Litewskim, [w:] Kalendarz Lubelski, Lublin 1985.

[16] Landecka H., Wokót koncepcji Placu Litewskiego w Lublinie, „Wiadomości Konserwatorskie”, 2008, (24): 74-81.

[17] Maj E., Arboretum F.t. Bieczyńskiego w ogrodzie Saskim w Lublinie, „Wiadomości Konserwatorskie Województwa Lubelskiego", 2007.

[18] Majdecki L., Historia Ogrodów, Warszawa 1978, PWN.

[19] Maleszyk P., Czego potrzebuje Lublin. Raport z badania jakości życia w dzielnicach Lublina, Lublin 2019.

[20] Mazurkiewicz J., Jurydyki Lubelskie, Wrocław 1965, Wyd. PAN.

[21] Mącik H., Historyczne aleje przydrożne we wspótczesnych granicach Lublina i ich ochrona konserwatorska, [w:] Trzaskowska E. (red.), Roślinność pasów przydrożnych Lublina. Potencjał i zagrożenia, Lublin 2017, s. 35-46.

[22] Niedźwiedź J., Ogrody publiczne dziewiętnastowiecznego Lublina w ideach, projektach i realizacjach Feliksa Bieczyńskiego, praca doktorska, Wydz. Ogrodnictwa i Architektury Krajobrazu SGGW w Warszawie, 2007.

[23] Przesmycka N., Przeobrażenia historycznych terenów zielonych Lublina do 1939 roku. In Teka Komisji Architektury, Urbanistyki i Studiów Krajobrazowych: Teka Commission of Architecture Urban Planning and Landscape Studies, vol. 1, 157-167. Lublin 2005, PAN O. Lublin.

[24] Przesmycka N., Przesmycki J.Z., Lubelska komisja Boni Ordinis i jej wpływ na rozwój przestrzenny miasta: The Commission of Boni Ordinis in Lublin and its impact on spatial development of the city, "Budownictwo i Architektura", vol. 7, 105-112, Wydawnictwo Politechniki Lubelskiej, Lublin 2010.

[25] Przesmycka N., Lublin przeobrażenia urbanistyczne 1815-1939, Wyd. Politechniki Lubelskiej, 2012.

[26] Pudelska K., Mirosław A., Zabytkowe ogrody klasztorne we wspótczesnym Lublinie, TEKA, 2011, p. 81-91. 
[27] Rewaloryzacja Ogrodu Saskiego w Lublinie. Zakres projektu oraz rys historyczny. Wydawca Gmina Lublin: Wydział Funduszy Europejskich Urzędu Miasta Lublin.

[28] Sierpiński, S.Z., Obraz miasta Lublina, Warszawa 1839.

[29] Wójciuk M., Specyfikacja kamienic i moderacja pogłównego Lublina z 1738, „Rocznik Lubelskiego Towarzystwa Genealogicznego", Tom VI, 2014 (2015), 170-278.

[30] Zieliński W.K., Monografia Lublina. Dzieje miasta Lublina, 1878.

[31] Żywicki J., Urzędnicy: architekci, budowniczowie, inżynierowie cywilni... Ludzie architektury i budownictwa w województwie lubelskim oraz guberni lubelskiej w Królestwie Polskim w latach 1815-1915, Wydawnictwo Uniwersytetu Marii Curie Skłodowskiej, 2010.

\section{Sources}

[1] APL, AmL, 1809-1874, sygn. 570.

[2] APL, AmL, sygn. 6252, p. 32-34.

[3] Architectural and Landscape Study of Plac Litewski, 2000.

[4] Cegliński J. wg A. Lerue, 1857, Muzeum Lubelskie Kat. 94.

[5] Cegliński J., Kolegiata św. Michała przed rozbiórką w latach 1846-1852.

[6] Łodzia-Bieczyński F., 1854, APL, AmL 1809-1874, sygn. 570.

[7] KRSW 3659, k. 22-40, KWL do KRSW z 30.III.1820.

[8] Plac Litewski w Lublinie. Studium architektoniczno-krajobrazowe, Lublin 2000.

[9] Plan miasta Lublina 1829, F. Bieczyński, Zb. Spec. Biblioteki H. Łopacińskiego.

[10] Plan Miasta Lublina z 1912 roku, M. Stelmasiewicz, APL, sygn. 8623.

[11] Plan miasta Lublina z 1919, APL, PmL, sygn. 13.

[12] Plan sytuacyjny przebudowy miejskich skwerów, H. Paprocki, Muzeum Lubelskie, nr inw. ML/RR/338.

[13] Ogólny i szczegótowy plan zabudowania obszaru ograniczonego ulicami Lipowa-Rury Jezuickie-Gtęboka oraz cmentarza w m. Lublinie, Archiwum LPU WP UM.

[14] Tretter J., Plan Der West Gazlizieschen Kreistadt Lublin nebst der umligenden Gegend, 1803, skala 1: 14.440, orgy. Kriegsarchiv Wiedeń, plan wyk. Pod kierunkiem Antoniego Mayera von Heldensfelda.

[15] Dąbek F., "The Arrival of General Zajączek to Lublin in 1826", oil painting.

[16] Restoration of Ogród Saski in Lublin - scope of the project and historical outline, information brochure, published by Gmina Lublin, 2013.

\section{Internet sources}

[1] http://www.sarp.krakow.pl/konkursy,149,Konkurs_na_Plac_Litewski_w_Lublinie.html (accessed 10.11, 2018 r.).

[2] https://docplayer.pl/43137719-Koncepcja-zmiany-zagospodarowania-placu-litewskiego-w-lublinie.html (accessed $10.11,2018$ r.).

[3] https://lublin.eu/mieszkancy/srodowisko/zielony-lublin/parki-w-lublinie/ogrod-saski/ (accessed 10.11, 2018 r.).

[4] https://pl.wikipedia.org/wiki/Pomniki_przyrody_w_Lublinie (accessed 10.11, 2018 r.).

[5] https://lublin.eu/gfx/lublin/userfiles/_public/lublin/lublin_w_ue/multimedia/ogrod_saski_folder.pdf.

[6] https://en.wikipedia.org/wiki/Jurydyka (accessed 10.11, 2018 r.).

[7] https://www.google.com/maps.

[8] https://www.geoportal.gov.pl.

[9] https://www.archivinformationssystem.at/detail.aspx?ID=1425049, [dostęp: 5 października 2020].

[10] http://teatrnn.pl/historiamowiona/swiadek/Maj\%2C_Euzebiusz_\%281940-_\%29?tar=44502. 


\section{Rola historycznej zieleni w kształtowaniu krajobrazu śródmieścia Lublina}

Streszczenie: Historyczne śródmieście Lublina kształtowało się w drodze przemian zarówno o charakterze spontanicznym, jak i planowanym. Najstarszą formą zaplanowanej zieleni istniejącą do dnia dzisiejszego na terenie śródmieścia Lublina, są ogrody klasztorne. Większość z nich nie zachowała do dnia dzisiejszego pierwotnego charakteru. Spowodowała to zarówno zmiana funkcji (i własności) niektórych założeń klasztornych, jak i zmieniająca się moda. Po raz pierwszy planowana zieleń jako element kompozycji urbanistycznej pojawiła się w Lublinie na początku XIX wieku. Porządkowane wówczas place, skwery i ulice (Plac Musztry, Krakowskie Przedmieście, place przed kościołami), oraz wytyczane nowe trakty komunikacyjne zyskały oprawę w formie nasadzeń drzew i krzewów. Niedługo później powstały pierwsze parki publiczne (Park na Czechówce, Ogród Miejski i Park Bronowicki). Specyficznym rodzajem zieleni miejskiej są historyczne cmentarze (przy ul. Lipowej, Kirkut, cmentarz przy kościele ewangelickim). Nieliczne sadzone w XIX wieku drzewa istnieją do dnia dzisiejszego, stanowiąc cenny element krajobrazu kulturowego i przyrodniczego miasta. W artykule przedstawiono charakterystyczne dla Lublina rodzaje założeń planowanej zieleni miejskiej, bazując na archiwalnych materiałach źródłowych, opracowaniach projektowych, literaturze i ikonografii. Przeobrażenia estetyki wskazanych obszarów badano w okresie od ich powstania, do chwili obecnej. Szczegółowej analizie poddano najważniejszą przestrzeń publiczna Śródmieścia Lublina - Plac Litewski.

Słowa kluczowe: Lublin, zieleń w śródmieściu Lublina, historyczna zieleń Lublina, Plac Litewski, Ogród Saski, „Baobab” 